\title{
Ipari eszközökkel megvalósított automata elektropneumatikus rajzgép
}

\author{
Szabó László \\ Villamosmérnöki és Mechatronikai \\ Tanszék \\ Debreceni Egyetem, Müszaki Kar \\ Debrecen, Magyarország \\ lazlo92@totalcar.hu
}

\author{
Dr. Tóth János \\ Villamosmérnöki és Mechatronikai \\ Tanszék \\ Debreceni Egyetem, Müszaki Kar \\ Debrecen, Magyarország \\ tothjanos@eng.unideb.hu
}

\author{
Dr. habil. Husi Géza \\ Villamosmérnöki és Mechatronikai \\ Tanszék \\ Debreceni Egyetem, Müszaki Kar \\ Debrecen, Magyarország \\ husigeza@eng.unideb.hu
}

\begin{abstract}
Absztrakt - A feladat célja egy elektropneumatikus rajzgép tervezése, összeállítása és múködtetése, melynek irányítását egy PLC végzi el úgy, hogy PC-s kezelö felületlétrehozására is sor kerül. A rajzgép mind kézi, mind automatikus rajzolási folyamatokat képes végrehajtani.
\end{abstract}

Kulcsszavak- Festo; Phoenix Contact; PLC; PC Worx; Visu+; OPC server;

\section{BEVEZETŐ}

A feladat célja egy elektropneumatikus rendszerrel megalkotott rajzgép tervezése és megvalósítása, melynek vezérlését egy PLC végzi. A rajzgép mind kézi, mind automatikus műveletek végrehajtására képes.

A megvalósítást egy eszközfelmérési és tervezési folyamat előzte meg, hogy a rajzgép szerkezetét milyen meglévő pneumatikus eszközökkel lehet megvalósítani, illetve a kiválasztott eszközök egymáshoz illesztése milyen módon oldható meg.

\section{A RAJZGÉP SZERKEZETÉNEK TERVEZÉSE}

A rajzgép 3 irányban képes elmozdulni: vízszintes irányban (X és Y irány), valamint függőleges (Z) irányban.

A vízszintes irányú mozgásokhoz $3 \mathrm{db}$ Festo DGC lineáris hajtómű lett felhasználva, azon belül két típus:

- 2 db DGC-18-300-KF-YSRW-A (Y tengely)

- 1 db DGC-18-200-GF-YSR-A-DL (X tengely).

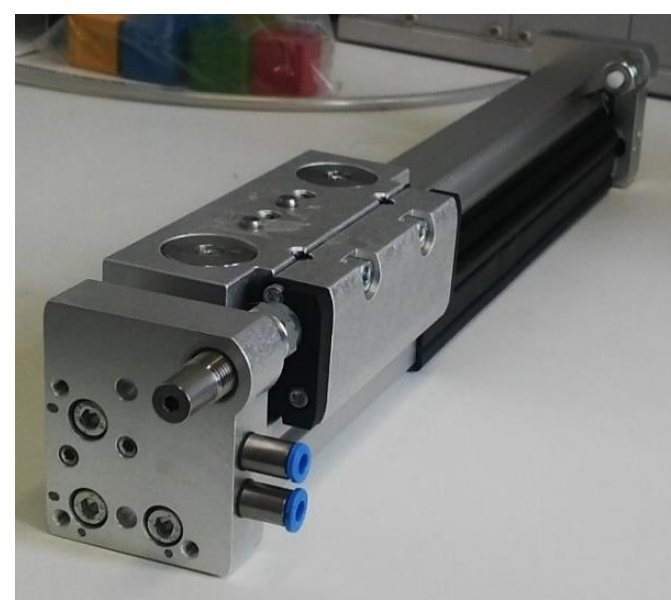

1. ábraX tengely, DGC hajtóműve

A pneumatikus végrehajtók lökethosszai eltérőek, a DGC18-300-as típus $300 \mathrm{~mm}$, míg a DGC-18-200-as $200 \mathrm{~mm}$-es lökethosszal rendelkezik.

A terv a két hosszabb lökethosszú hajtómü (Y irány) elhelyezése egymással párhuzamosan, melyek szánjaira merőlegesen kerül illesztésre a harmadik hajtómű (X irány). A hajtóművek egymáshoz, valamint a munkaasztalra való illesztéséhez sarokacél elem tervek készültek a hajtóművek 2-2 végén, a szánjain található menetes furatok átmérői és azok távolságai alapján. A sarokelemek a későbbiekben legyártatásra kerültek, azok méretpontosságának igénye miatt.

Az X irányban mozgó szánra került a rajzoló eszközt $\mathrm{Z}$ irányban mozgató munkahenger. Ehhez egy Bosch-Rexroth GPC-BV típusú kettős működésű munkahenger került kiválasztásra - melynek lökethossza nem túl nagy (100 mm) -, amely eleget tesz a szükséges tervezési-mozgási feladatnak. A rajzoló eszköz rögzítése (toll/ceruza)a munkahenger dugattyújának végére kerül a kialakított menetes furatok segítségével. 


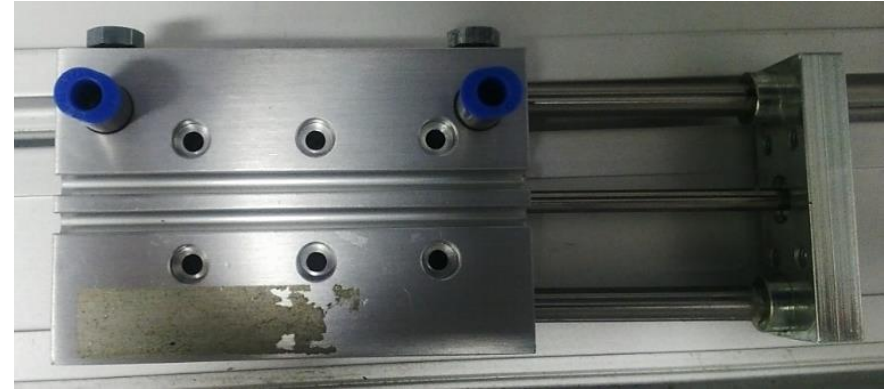

2. ábra A rajzoló eszköztmozgató munkahenger ( $\mathrm{Z}$ tengely)

\section{A RAJZGÉP ÖSSZEÁLLÍTÁSA}

\section{A. A rajzgép szerkezeti összeállítása}

A DGC hajtóművek az előzetesen megtervezett és legyártatott sarokelemek segítségével kerültek összeállításra a 3. ábrán látható módon.

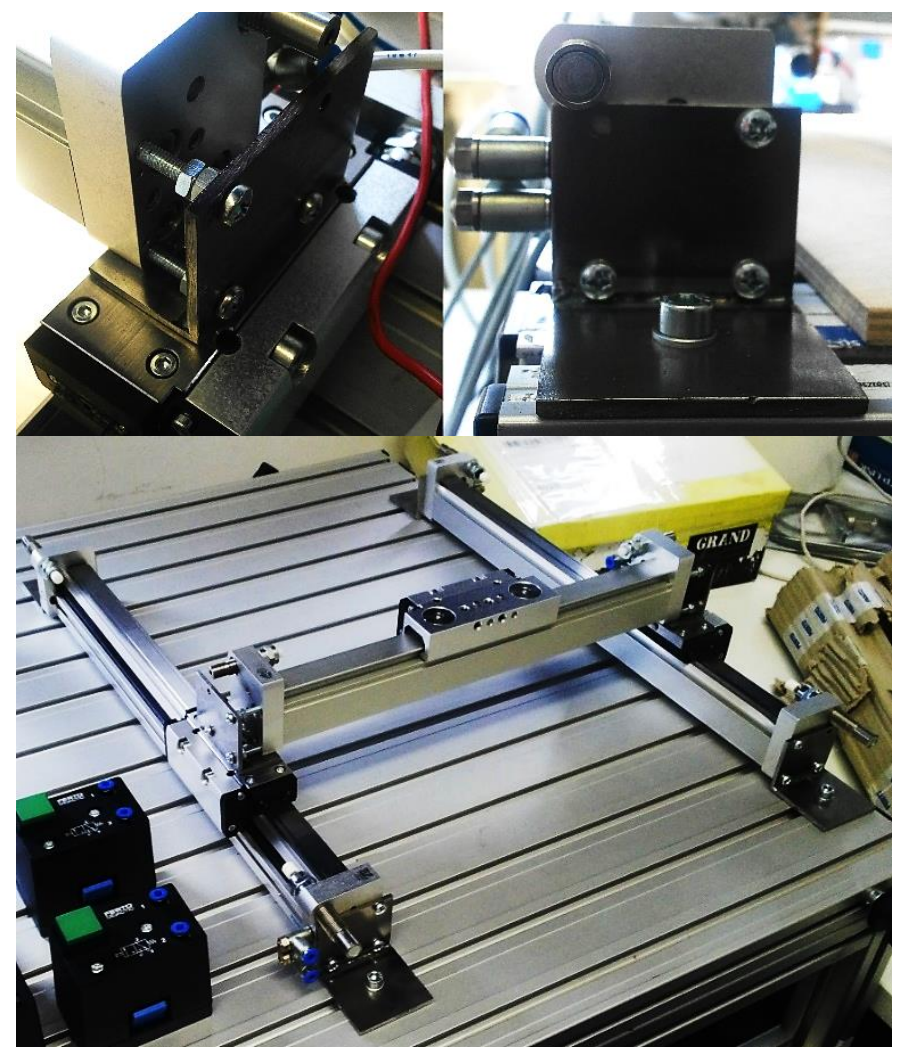

3. ábra A DGC hajtúművek egymáshoz illesztései

A GPC-BV ( $\mathrm{Z}$ irányú) munkahenger az X irányú hajtómű, szánjára került felrögzítésre egy sarokelemmel. A rajzoló eszköz rögzítése a $\mathrm{Z}$ tengelyirányú munkahenger dugattyúján valósult meg. A GPC munkahenger, és a rajzoló eszköz illesztését a 4. ábra szemlélteti.

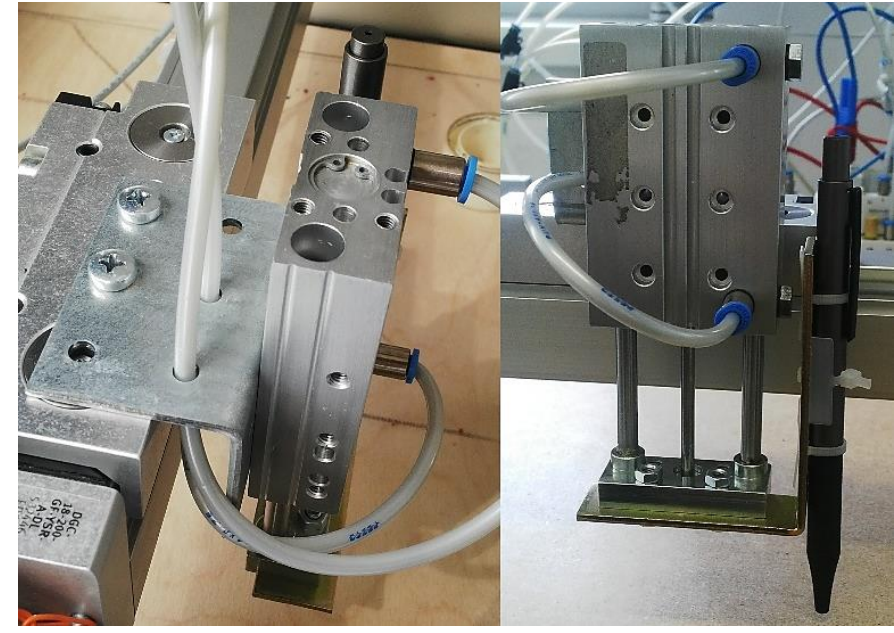

4. ábra A Zirányú munkahenger és a rajzoló eszköz illesztése

A pneumatikus végrehajtók összeillesztését követően meghatározásra került egy Home pozíció, amely alapján felvehető a Descartes-koordináta rendszer és annak irányai, mely az 5. ábrán látható. A Home pont felvételének célja a jó ráláthatóság biztosítása a munkaterületre a gép működési folyamatai közben.

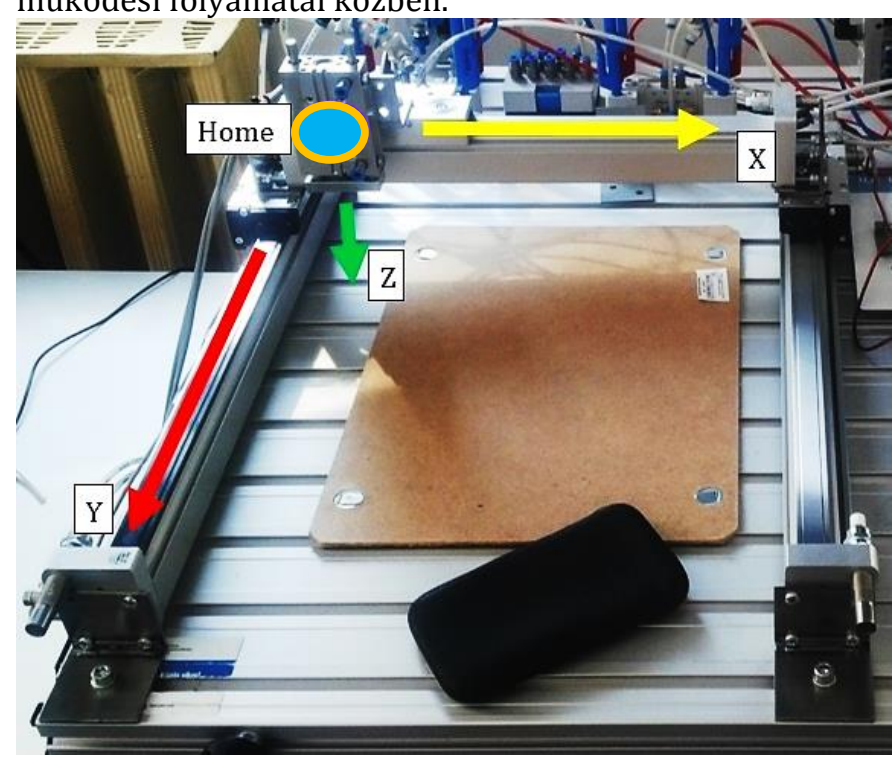

5. ábra A felvett Descartes koordinátarendszer

\section{B. Elektropneumatikus vezérlési kör kialakítása}

A szerkezeti összeállítást követően kialakításra került egy elektropneumatikus kapcsolási kör, mellyel vezérelhetők a mozgási irányok vezérlései, valamint az X-Y irányú mozgások bármely pozícióban megállíthatók. Ehhez egy kapcsolási vázlatot kellet elkészíteni a FluidSIM nevű szoftverben, tervezés és modellezés céljából. 


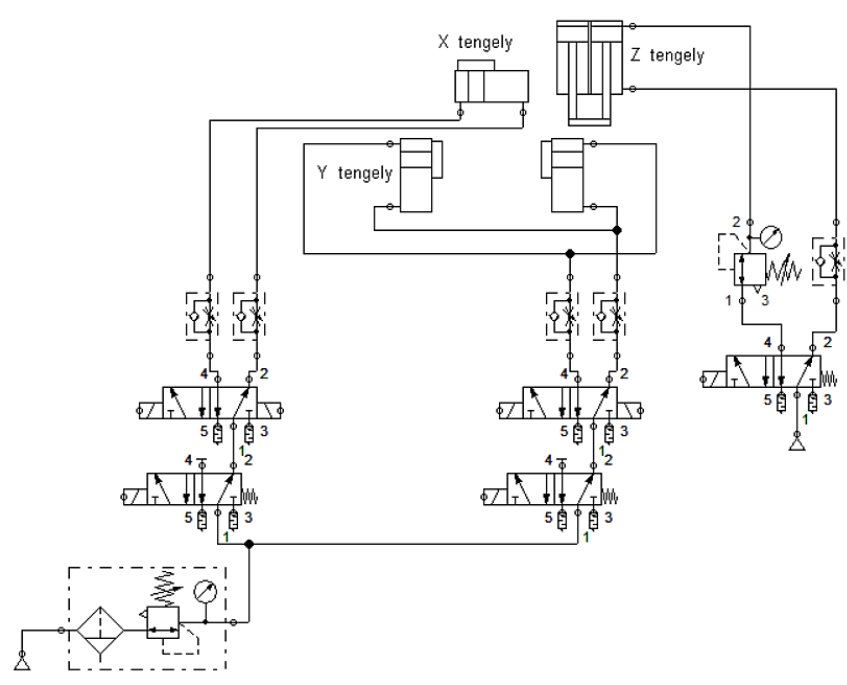

6. ábra A vezérlési kör kapcsolási vázlata

Az elektropneumatikus kör két fő részre osztható: a vízszintes mozgások és a $Z$ irányú mozgás vezérlése.

Útváltó szelepeknek 5/2-es mágnes szelepek lettek alkalmazva mind X és $\mathrm{Y}$, mind $\mathrm{Z}$ irányokhoz.

Az X és Y irányú mozgásokhoz egy-egy Festo VUVGL10-B52-T-M5-1P3 típusú, 5/2-es bistabil mágnesszelep lett kiválasztva. A bistabil szelepek választásának indoka, hogy a későbbiekben az egy tengelyhez tartozó két mozgási irány vezérlő jeleit programozás útján lehessen meghatározni.

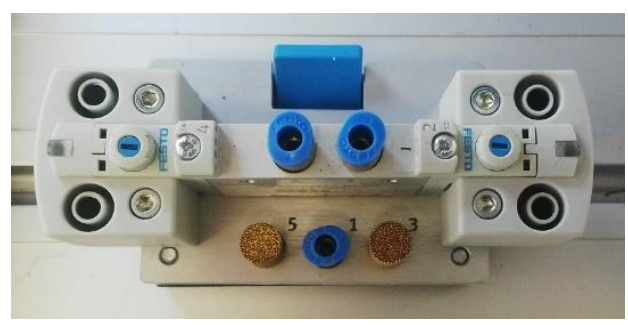

7. ábraEgy VUVG-L10 bistabilmágnesszelep

A vízszintes irányok útadó szelepeinek táplevegő csatlakozásához bekötésre került egy Festo által gyártott CPV10-VI szelepsziget 1-1 monostabil mágnes szelepe. A szelepsziget bekötésének segítségével valósítható meg az X és Y irányú mozgási folyamatok megállítása és újraindítása. A bekötés módját a 6 . és a 8 . ábra szemlélteti (afel nem használt csatlakozások le lettek dugózva).

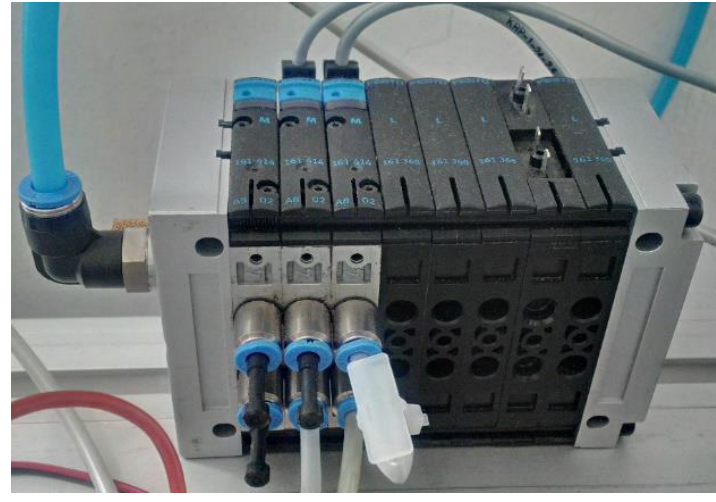

8. ábra CPV10 szelepsziget

A tápellátó szelepek alaphelyzetében a két útadó szelep táplevegője szabadon áramlik, a vízszintes mozgások megtörténnek. Ha vezérlő jelet kapnak, a szelepek átbillennek, megszakítva az útadó szelepek táplevegő ellátását, így az adott irányú mozgási folyamatok megállnak.Ezek a szánok mindaddig álló helyzetben maradnak, míg a vezérlőjel meg nem szűnik.

A mozgási sebességek szabályozásához fojtóvisszacsapó szelepek kerültek bekötésre.

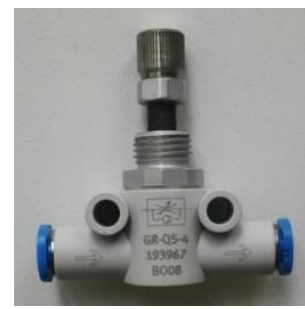

9. ábra Az egyik alkalmazott fojtó-visszacsapó szelep

Kimenő ági fojtást alkalmaztam, így érve el az egyenletes dugattyúterheléseket és mozgási folyamatokat (6. ábra).

A függőleges irányért felelő munkahenger vezérléséhez egy VUVG-L10-M52-RT-M5-1P3típusú 5/2esmonostabilmágnesszelep került felhasználásra.Feladata a rajzoló eszközt függőleges irányba mozgató munkahenger állapotának megadása. Ha a szelep reléje kapcsol, a dugattyú kitolódik, rögzítve a rajzolóeszköz hegyét a rajzlap felületre. Mindaddig külső végállásban marad, amíg a relé jelet kap. A jel megszúnése esetén a dugattyú visszatér alap állapotába.

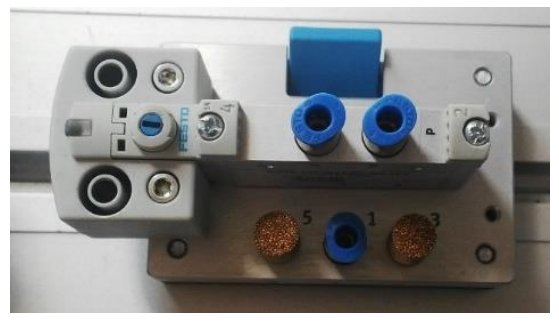

10. ábra A felhasználtmonostabilmágneszelep

A dugattyúrúd felőli oldalon bekötésre került egy fojtóvisszacsapó szelep. Célja a kitolási sebesség lekorlátozása, 
a rajzoló eszköz hegyének és a munkafelületnek (rajzlap) a védelmét szolgálva.

A másik ágba került egy nyomásszabályzó szelep. Alkalmazására a rajztábla egyenetlenségeinek kiküszöbölése miatt került sor.

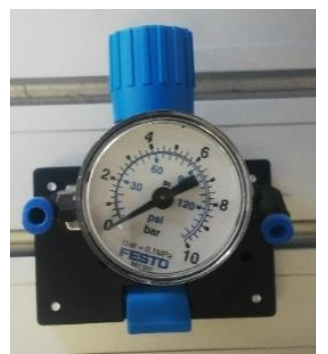

10. ábra A felhasznált nyomásszabályzó

A rajzoló (ceruza/toll) eszköz rögzítése a $\mathrm{Z}$ irányú munkahenger dugattyúján úgy lett beállítva, hogy a hegye korábban ér le a rajztábláig, mint ahogy a dugattyú eléri véghelyzetét. Ezzel a megoldással a domború-homorú felületi hibáktól függetlenül a rajzoló hegy mindig hozzáér a rajzlaphoz.

\section{Az érzékelők és a PLC kiválasztása}

Festo SME-8M REED kapcsolóklettek beépítve az automatizált mozgások megvalósításához:hat azegyik hosszabb végrehajtón (Y tengely), négy pedig a röviden (X tengely) lett elhelyezve.

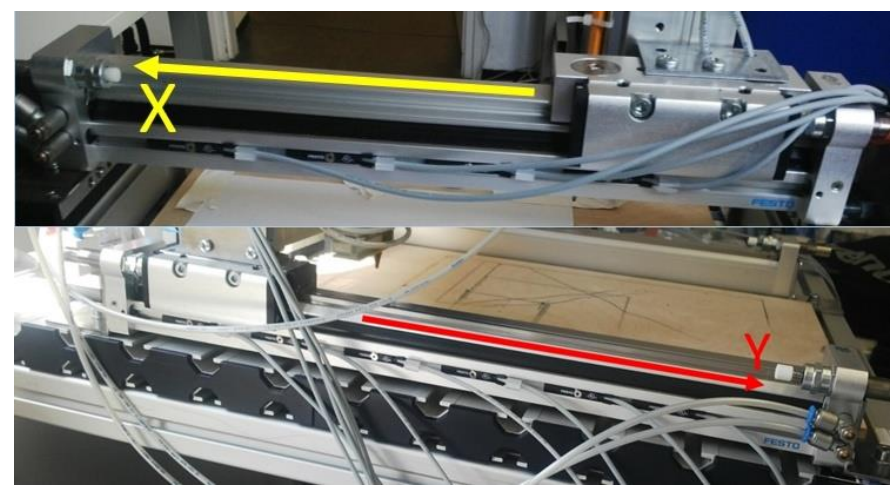

11. ábra A DGC hajtóművekre felhelyezett REED szenzorok

A REED szenzorok alaphelyzetben nyitottak (NO). Ha az adott irányban mozgó szán eléri az egyik szenzort, az kapcsol, jelet ad ki. Programozás útján meghatározható, hogy a szenzorok érzékelés esetén adjanak valamilyen feltételt a mozgások, pozícionálások kapcsán, vagy az ellenkezője történjen. Tehát ezekkel a szenzorokkal valósul meg a vízszintes irányú mozgások pozícionálása automatikus üzemmód esetén, valamint hogy a rajzoló mikor legyen lent a munkaterületen.

A választott PLC egy Phoenix Contact ILC 131 ETH típus. 8 bemeneti és 4 kimeneti ponttal rendelkezik, valamint ismeri mind az 5 szabványos programozási nyelvet.

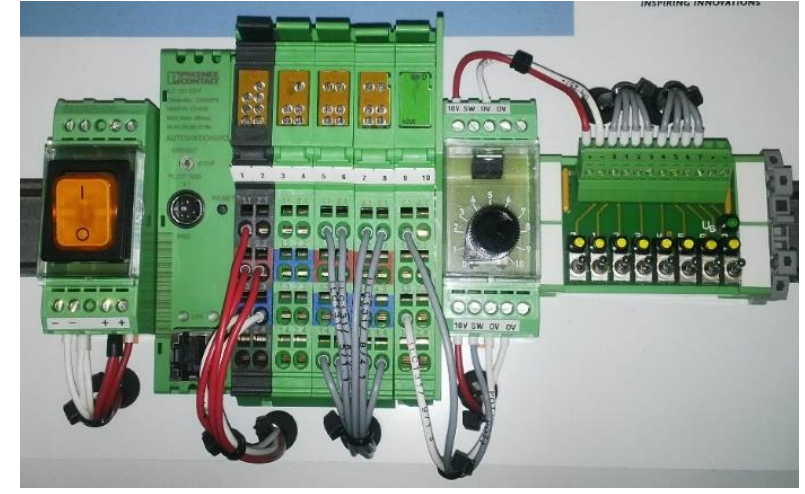

12. ábra Az ILC 131 ETH PLC

A szükséges be- és kimenetek száma 10 (az érzékelők száma) és 7 (a mágnesszelepek kimeneteinek száma). Ezért

bővítő modulokatkellett alkalmazni.Egy IB IL 24 DI 4-ME bemeneti modult 4 bemeneti ponttal, valamint egy IB IL 24 DO 4-ME kimeneti modult 4 kimeneti csatlakozással.

A mágnesszelepek, a szenzorok és a PLC elektromos összekötésével lett a rajzgép összeállítása teljes. Innentől a működtető szoftver megírása maradt hátra.

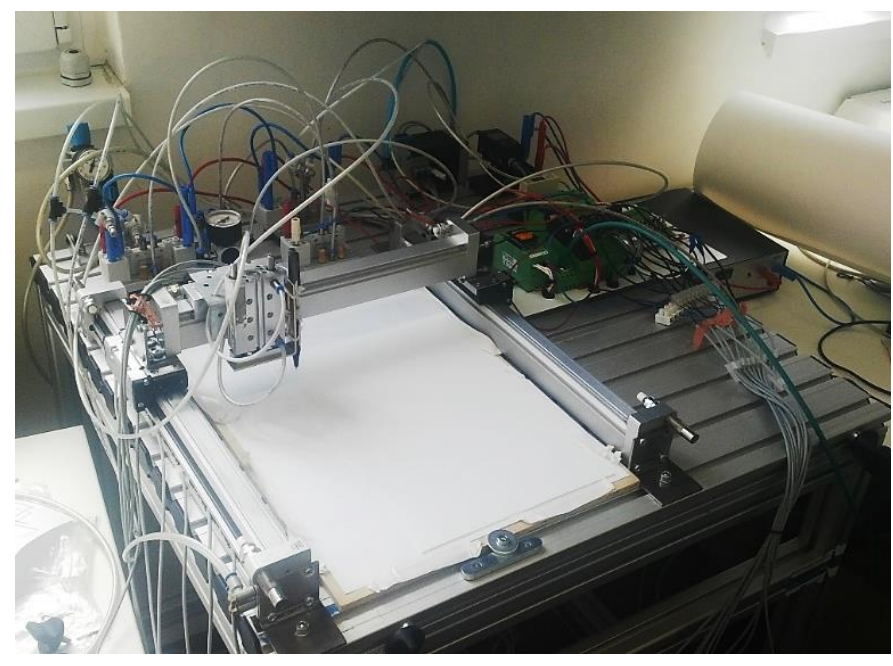

13. ábra Az összeállított rajzgép

\section{AZ IRÁNYÍTÓ PLC PROGRAM}

A PLC programozásához a PC Worx 6.30.1202 verziójú szoftver lett felhasználva.A programozás során a Létra (LD) és Funkcióblokkos (FBD) programozási nyelvek lettek alkalmazva.A véglegesen felhasznált és megírt program összetétele többrétű, mely az alábbi részekre tagolható:

- egy kézi irányítási rész, 
- 4 automata alakzat rajzolási lehetőség (3 különböző méretű négyzetés egy derékszögű háromszög),

- az X és Y irányok útadóinak billentése, szelepsziget vezérlése,

- a Z irányú rajzoló eszközt mozgató és rögzítő szelep vezérlése,

- $\quad$ egy Vész Stop gomb,

- $\quad$ egy Home pozíció gomb,

- $\quad$ egy A4-es papírlaphoz tartozó Origo gomb.
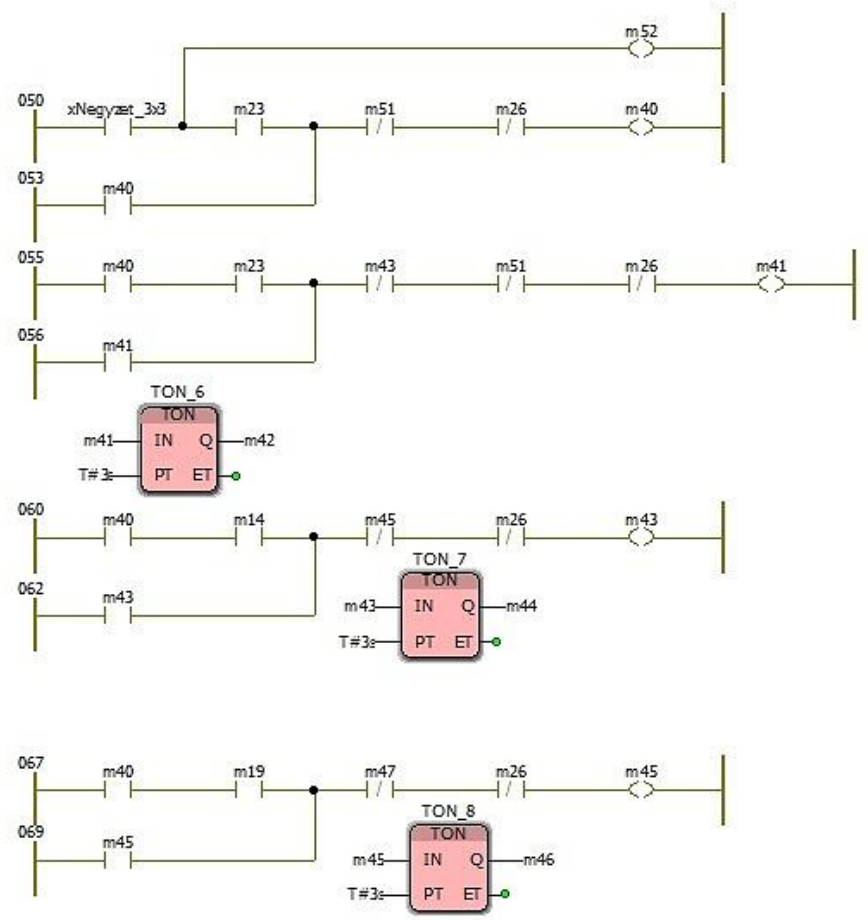

14. ábra Programrészlet (3x3-as négyzet)

$\mathrm{Az}$ alkalmazott érzékelők számának függvényében felvehető egy síkbeli mátrix (15. ábra), melynek metszéspontjai különböző viszonyítási és alkalmazási pontokként vehetőek fel, úgymint folyamatok kiindulási pontja, vagy mozgások határoló- vagy végpontjai.

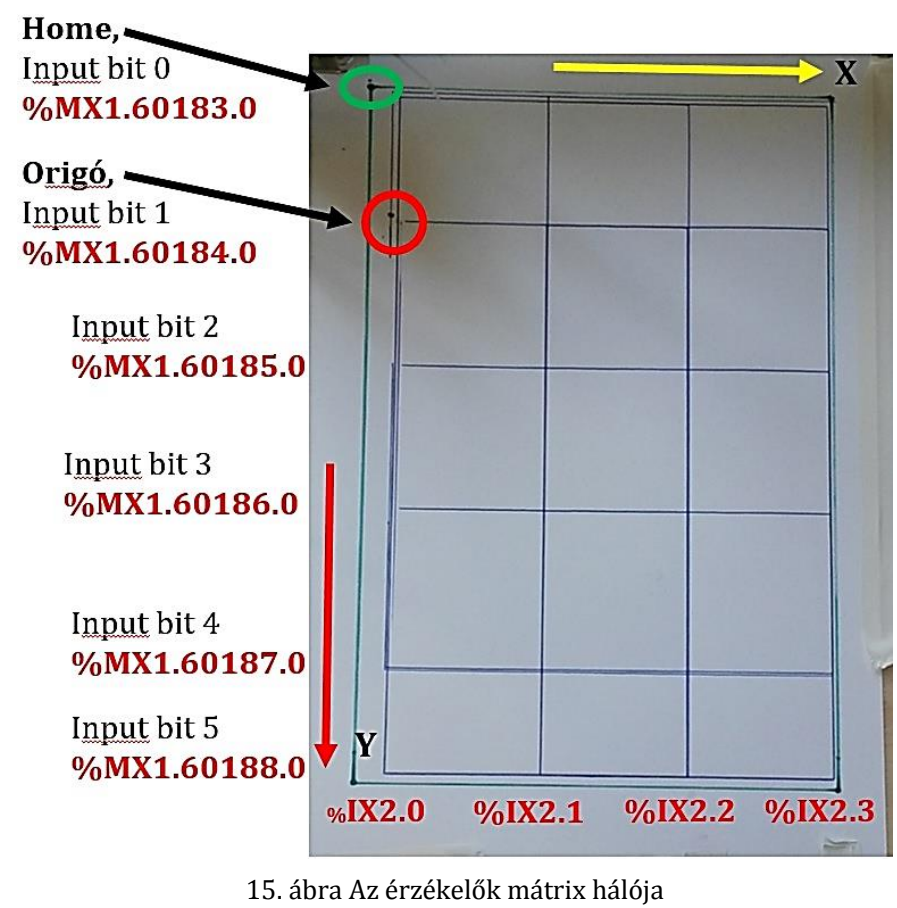

A felhasznált $10 \mathrm{db}$ érzékelővel X irányban 4, Y irányban 6 pont vehető fel, így felrajzolható egy 4x6-os mátrix. A 15. ábrán látható tollal felrajzolt kék vonalak jelzik az érzékelők által behálózott területet. A zöld filctollal rajzolt - négyzet (befoglaló négyzet) a hajtóművek maximális mozgási területe.

\section{AZ OPC SZERVERREL IRÁNYÍTOTT KEZELŐFELÜLET ÉS A KÉSZÍTHETŐ RAJZOK BEMUTATÁSA}

Az irányító kezelőfelület létrehozásához a Visu+ 2.42-es verziójú szoftver lettfelhasználva. A rajzgép irányítása egy OPC szerveren keresztültörténik. Az OPC szerverrel lehetőség nyílik Windows operációs rendszeren futó szoftverek és ipari eszközök - jelen esetben a PLC-PC - közötti kommunikáció létrehozására.

\section{Rajzgép kezelőfelülete}

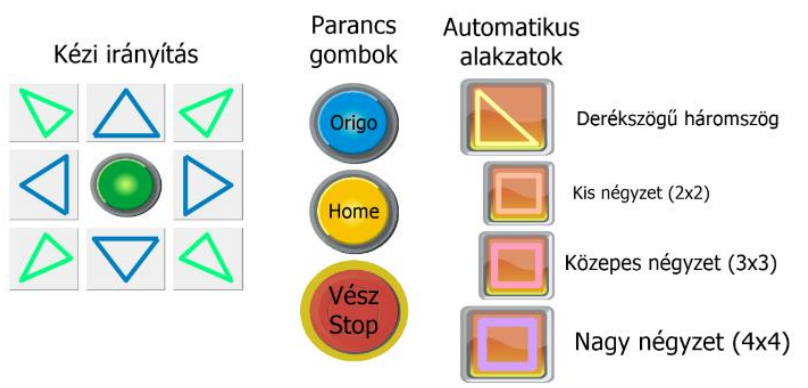

16. ábra A PC-s irányító kezelőfelület

A kezelőfelület 3 fô részre tagolható a 16. ábránlátható módon:

- kézi irányítás,

- parancs gombok, 
- automatikus alakzatok.

\section{A. Kézi irányítás}

A kék színnel ellátott gombok a tengely irányú mozgások, a zöld színű gombok a ferde irányú mozgások végrehajtására szolgálnak.Aközépső zöld kapcsoló gomb a rajzoló eszköz fel-le mozgatását, rögzítését szolgálja.Amíg a gomb benyomva van, az eszköz hegye a rajzlapon marad.

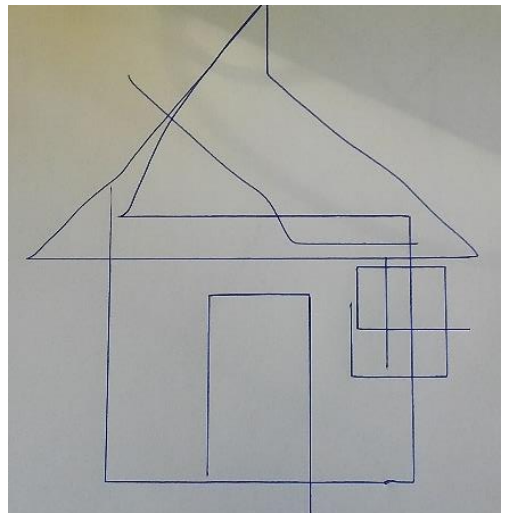

17. ábra Rajzolási példa kézi üzemmóddal

\section{B. Parancs gombok}

Három gombot hoztam létre: Origo, Home, és Vész Stop. Az Origo gomb létrehozását az A4-es rajzlapra való méretezés indokolja, mivel a munkaterület megközelítőleg egy ekkora rajzlap területének felel meg. A gomb lenyomásával a rajzoló egység bármely pozícióból a 15 . ábrán feltüntetett Origó pontba mozog. Ez a pont az automatikus rajzolási folyamatok kiindulási feltétele.

A Home gomb lenyomásával az egység visszatér a munkaterületen kijelölt Home (kiindulási) pozícióba.

A Vész Stop gomb megnyomásával bármilyen rajzolási folyamatot leállít, és visszatér az egység a Home pozícióba.

\section{Automatikus alakzatok}

Ezekkel a gombokkal indítható a 4 automatikus alakzatrajzolás, 3 különböző méretű négyzet, ésegy derékszögű háromszög.

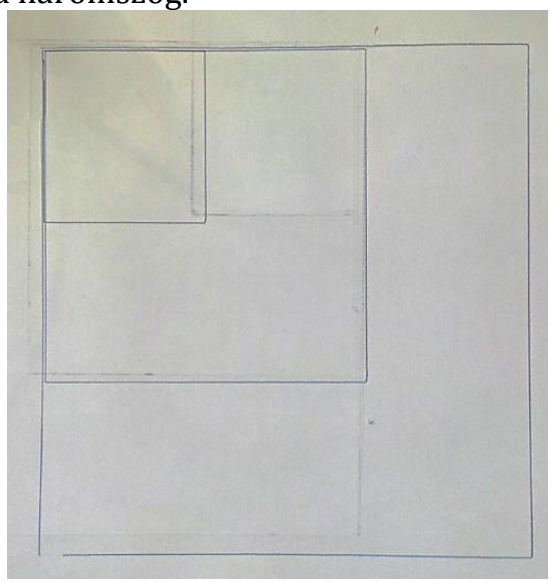

18. ábra A különböző méretű négyzetek
Négyzetek esetén $2 \times 2$-es, $3 \times 3$-as, és $4 \times 4$-es méretek rajzolására van lehetőség (18. ábra). 2x2-es négyzetnél 1-1 szomszédos érzékelőről van szó, 3x3-asnál 2 szomszédos érzékelőről, és így tovább.

A derékszögű háromszög rajzolása egy $3 \times 3$-as területen belül zajlik.

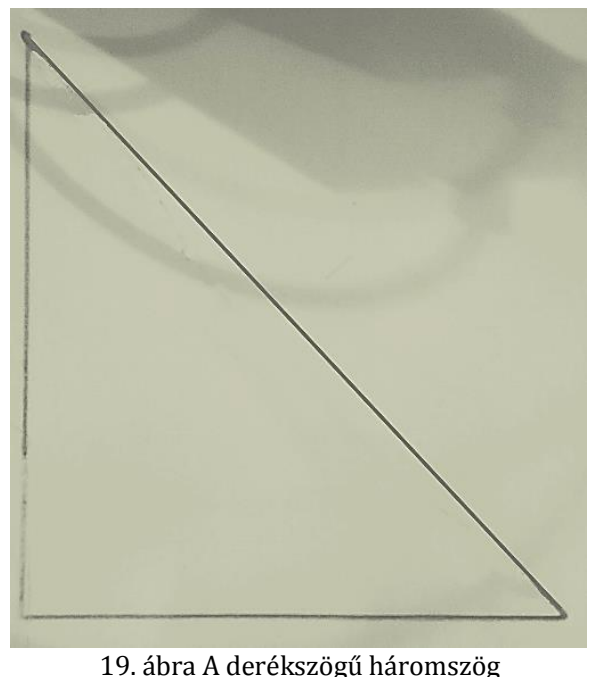

\section{VI. ÖSSZEFOGLALÁS}

Megtervezésre és megvalósításra került egy elektropneumatikus rajzgép, melynek irányítását PLC végzi. Az irányító program létrehozásához Létra- és Funkció blokkos programozási nyelvek együtteselett felhasználva. A gép működtetéséhez a kezelőfelület létrehozásához vizuális gombok lettek leprogramozva, melyeknek a kommunikációja OPC szerveren keresztül valósul meg.

A rajzgép rendelkezik mind kézi, mind automata üzemmódokkal. Az automata üzemmódban egyszerű alakzatok megrajzolása lett leprogramozva.

\section{HIVATKOZÁSOK}

[1] Hahn Emil, Harsányi Gábor, Lepsényi Imre, Mizsei János: Érzékelők és beavatkozók. Mủegyetemi Kiadó, Budapest, 1999.

[2] Lambert Miklós: Szenzorok, Elmélet ésgyakorlat. Kiadó: InvestMarketing Bt. Budapest, 2009. ISBN: 9789638740113

[3] Dr. Ajtonyi István: PLC és SCADA-HMI rendszerek I. PLC programozásaz IEC 61131-3 szabvány szerint. AUT-INFO Kiadó, Miskolc, 2007. ISBN: 9789630631655

[4] Dr. Ajtonyi István: PLC és SCADA-HMI rendszerek II. \& Ipari kommunikációs rendszerek II. AUT-INFO Kiadó, Miskolc, 2008.

[5] Dr. Ajtonyi István: PLC és SCADA-HMI rendszerek III. AUT-INFO Kiadó, Miskolc, 2008. 